\title{
POSSIBLE WORLDS IN THE PRECIPICE: WHY LEIBNIZ MET SPINOZA?
}

\author{
UDC 111.1+14 LEIBNIZ G.W.+14 Spinoza B.
}

\author{
Vassil Vidinsky \\ Sofia University "St. Kliment Ohridski", Faculty of Philosophy, \\ Department of History of Philosophy, Bulgaria
}

\begin{abstract}
The main objective of the paper is to give initial answers to three important questions. Why did Leibniz visit Spinoza? Why did his preparation for this meeting include a modification of the ontological proof of God? What is the philosophical result of the meeting and what do possible worlds have to do with it? In order to provide answers, three closely related manuscripts by Leibniz from November 1676 have been compared and the slow conceptual change of his philosophical apparatus has been analyzed. The last of these manuscripts was presented and read in front of Spinoza. Around that time Leibniz abandoned the idea of plurality of worlds (cf. Tschirnhaus) and instead proposed the idea of possible worlds, thus introducing possibility into the (onto/theo)logical structure itself in order to avoid the "precipice" of Spinoza's necessity. What is interesting, however, is how exactly this conceptual change occurred at the end of 1676 and what its philosophical and methodological implications are.
\end{abstract}

Key words: Leibniz, Spinoza, possible worlds, plurality of worlds, ontological proof of God, qualities.

\section{1676: THE MEETING}

The meeting of Gottfried Leibniz and Baruch Spinoza is a remarkable event - both from a conceptual-biographical point of view and from the perspective of history of philosophy. First of all, this is a conversation between two almost irreducible, emblematic and fundamental philosophical worldviews, whose (direct or delayed) influence in the following centuries is perceptible and structurally determining, while, on the other hand, it is the last important contact of Spinoza before his death three months later. Especially curious is also the long (and documented) philosophical preparation of Leibniz before his visit; furthermore, during the meeting Leibniz exposes the ontological proof of the existence of God. The "silence" on the part of Spinoza is, of course, also important and

Received November 30, 2017 / Accepted January 15, 2018

Corresponding author: Vassil Vidinsky

15, Tzar Osvoboditel Blvd., 1504 Sofia, Bulgaria

E-mail: vidinsky@phls.uni-sofia.bg 
expected - we have no record of his attitude regarding this meeting, and, in this sense, the latter is one-sided. Moreover, the change that occurs in Leibniz precisely during this period and as a consequence of his visit to the Hague, is impressive. Last but not least, the official attempt to cover up the motives for the visit, the content of the conversations and the length of stay is also symptomatic. However, the most important aspect this case is the following: there is something theoretic-mythological in the meeting, insofar as it reaffirms the slow but irreversible process of unfolding of the idea of possible worlds.

And so, from 18 to 21 November Leibniz visited Spinoza. ${ }^{1}$ At that time, Spinoza (44) is a scandalously controversial and dangerous figure, and Leibniz, though young (30), is already a part of the institutional status quo. As there are many details missing, the interpretative risk is unavoidable, but it can be at least partially mastered through letters and documents. Luckily, we have them both.

\subsection{Participants}

The direct participants in the meeting are only Leibniz (01. 07. $1646-14.11 .1716)$ and Spinoza (24. 11. 1632 - 21. 02. 1677). However, indirectly, extramurally, but still essentially, Ehrenfried von Tschirnhaus - a commentator, correspondent and critic of Spinoza, as well as a man who is acquainted to Leibniz (from September 1675) and who is also his correspondent; ${ }^{2}$ Georg Hermann Schuller - a German physician in Amsterdam, one of the closest friends of Spinoza; as well as Henry Oldenburg - the secretary of the Royal Society participated. All of them play a different role and, more importantly, have a different attitude towards the philosophical systems of Leibniz and Spinoza.

\subsection{Direct Context of the Meeting}

Leibniz arrives on a yacht (his trip starts from Paris and ends in Hannover, and on the way he passes through London and the Hague) and carries a letter from Henry Oldenburg, which he unexpectedly decides not to give to Spinoza ${ }^{3}$. At that time, Leibniz has already developed his own mathematical methodology and he carries with himself a small wooden box - the arithmetic calculating machine (Stewart 2006, 1, 2).

Spinoza rents his residence in the Hague, next to one of the canals (Paviljoensgracht) of the northern suburb. He is 44 years old and has a birthday the same month. During the day he grinds lenses for microscopes and telescopes, and during the night he works on his metaphysics (Stewart 2006, 1, 3).

The two of them are at different stages of their development. Leibniz is actually on the way and travels around; he is still reasoning about his own (mathematical) discoveries and "carries them" with himself to different fields of knowledge and of existence: real, phenomenal, ideal ${ }^{4}$ (the connection between the "new analysis" and the proof he offers Spinoza is obvious). Spinoza, on the other hand, is rather grinding his completed

\footnotetext{
${ }^{1}$ November $8-11$, in old style. All dates are given in new style.

${ }^{2}$ Cf. „Über Spinozas Ethik“ (AA VI, 3, 384), as well as the letters to Spinoza No. 59 (January 5, 1675), No. 80 (May 2, 1676) and No. 82 (June 23, 1676), cf. Spinoza 2002.

${ }^{3}$ Oldenburg is amazed: "I cannot even guess for what reason you did not deliver my letter to Spinoza [Quid causae sit, quod Spinosae non tradidisti literas meas, divinare equidem non possum]". For more details about this case and the fear of Leibniz, cf. Malcolm 2003.

${ }^{4}$ Vidinsky 2008.
} 
metaphysics and for him the details would no longer change the general arrangement; he does not travel and the feeling of midnight silence is intrusive.

\subsection{The Leibniz's Official Version of}

Leibniz hides both his lengthy preparation for the meeting and the specific details around his stay: he officially asserts he has just happened to pass by the Hague and has seen Spinoza for a couple of hours, sharing with him only a few anecdotes during that time. ${ }^{5}$ Presented in this way by Leibniz, the spinozism seems so unwise that it is not even worth fighting or talking about it; the suggestion is that nothing could be expected from the meeting except a short courteously-secular conversation; as it has happen. Spinoza is a dangerous figure - from a political, theological, theoretical and even social point of view, and the visits require great caution.

\subsection{Information on the Meeting from Gallois and Friedrich}

The event, the meeting and the situation turn out to be quite different. The information is sufficient for us to assert at least the following: Leibniz travels to the Hague purposefully and exactly with the intention of meeting Spinoza; his preparation lasted for at least several months and his interest will continue for years. The purpose, of course, is to discuss and analyze the deepest philosophical grounds or problems. Leibniz stays at Spinoza's for at least 3 days; they talk several times, and these conversations are long. ${ }^{6}$ The other man (except Jean Gallois), with whom Leibniz shares more freely his curiosity, interest and respect for Spinoza, is Johan Friedrich, with whom in May 1677 he shares that he will examine in detail all of Spinoza's manuscripts, which have survived after his death, and he hopes to make copies of what is valuable. ${ }^{7}$

\subsection{The Text from the Meeting (A81)}

Among other things, we have access to a very curious document: a short metaphysicallogical exposition, which presents proof for the existence of God (later, Leibniz will return to this important idea, cf. Blumenfeld 1972). At the bottom corner of the document it is claimed that it was written by Leibniz himself and in front of Spinoza, and after that it was read out loud ${ }^{8}$. This is the only written testimony from these three days. The exposition is a non-trivial modification of the classical ontological proof known to Leibniz from the critique of Thomas of Aquino (see Leibniz 1992, 63; April 15, 1676) and from Descartes' Meditationes (quoted explicitly in the Scholium in the proof). The

\footnotetext{
${ }^{5}$ Cf. the letter to Ernest von Hesse-Reinfels of August 14, 1683 in Malcolm 2003: 227, note 5; Theodicy, §376 Leibniz 2007, 355.

6 "Spinosa est mort cet hyver. Je l'ay veu en passant par la Hollande, et je luy ay parlé plusieurs fois et fort long temps" (AA 11, 1, 568; letter to Abbe Jean Gallois of 1677). Further in the letter Leibniz describes what happened during the conversations.

7 "Werde ich alle Manuscripta Spinosae sehen, und verhoffentlich von denen so es würdig copie haben können" (Malcolm 2003, 227, fn. 5).

8 "I showed this argument to Mr. Spinoza when I was at the Hague, and he thought it to be sound. Since he contradicted it at first, I wrote it down and read this paper to him" - Leibniz 1992, 103 (about the Latin original, cf. Leibniz 1992, 102).
} 
title, put forward by Leibniz himself, is: That a Most Perfect Being Exists (AAVI, 3, 578579; 1989, 167-168; 1992, 100-103; Stewart 2006, 1, 4).

The manuscript is not about possible worlds, but inside it we find:

1. Introduction of the possibility in the onto(theo)logical structure;

2. Indirect distinction between the compossible and incompossible through the problem of qualities (a common problem for God, the world and the individual);

3. Presentation (in the form of a proof) of the qualities as compatible (compossible) in a single subject; and this is of crucial importance for the relation between multiplicity and possibility.

\section{1675-1676: BEFORE THE MEETING}

1. Why does Leibniz visit Spinoza? 2. Why does his preparation (and the visit itself) involve this modification of the ontological proof of God? 3. What is the philosophical result of the meeting and what do possible worlds have to do with it?

In order to answer these three questions we need to go back at least a year earlier. The preparation is far richer than the text presented to Spinoza - in itself this is also revealing of what Leibniz wants to show and wants to hide from his host. We do not know, of course, what the conversations between the two of them exactly contained, but the notorious tact of Leibniz probably did not allow him to give an explicit criticism.

\subsection{De Summa Rerum: the Philosophical Notes from the Last Year}

Leibniz discovers the mathematical analysis (an extremely important turning point for his entire worldview) during the autumn of 1675. In direct relation to this, from December 1675 to April 1676, he writes many mathematical and philosophical texts and in them he makes careful conceptual or thematic considerations. After April, the writing of the notes ceases, but starts again around the meeting with Spinoza - between October and December 1676. These manuscripts are extremely interesting and fluid readings and some of them are united under the general and symptomatic title De Summa Rerum. Let us now turn to them.

In December (1675) Leibniz reflects in On Mind, the Universe and God (A57; Y1) ${ }^{9}$ on the essential difference between the following two procedures: the process through ideas and the process through definitions - "...processum per ideas, et processum per definitiones..." (Leibniz 1992: 2). This is essentially the difference between thinking and speaking. Every procedure of speaking (definitions, signs) contains within itself a thinking procedure (ideas); unlike the process through ideas, in the process through signs the thought is fixed (frozen) and intuited in its entirety. The related definitions form a proof. The procedure through definitions relates to the procedure through ideas like the procedure through drawings to the procedure through pure imaginations - processum per simplices imaginations - which (must) from wandering become established (Leibniz 1992, 2). Exactly the same establishment will happen during the next year in De Summa Rerum. The manuscript On Mind, the Universe and God is essential because it marks the

\footnotetext{
${ }^{9}$ The letter and the subsequent number mark the texts from the academic edition (A) or from the Yale's bilingual edition $(\mathrm{Y})$.
} 
boundaries of the analysis and gives a key to understanding of the meeting with Spinoza. Here there is, of course, also talk about what is possible and what is impossible - a typical topic for Leibniz, - but in this case the most interesting thing is the statement that we have ideas for simple things and only signs for composite ones. This means that the mechanistic gathering of signs does not result in a whole idea, or, in other words, we cannot speak about one thing's possibility only from the fact that his characteristics ${ }^{10}$ are individually conceivable. Thus we also cannot judge about the impossible only through thinking; about it we know only that it is incompatible with the necessary.

In February, Leibniz writes that all possibilities cannot exist simultaneously (Leibniz 1992, 21; A60; Y3), and further in the text he says explicitly: together, all possibilities cannot be understood by anyone, as they suggest contradiction. This important idea about the incompossibility of the possibilities already has its apparent intuition and principal ground. ${ }^{11}$ However, it is good to remember that even in a letter to Magnus von Wedderkop (1671) Leibniz already says that God chooses between infinite possibilities (AA 11, 1, 186; 1989, 146; 2005, 3).

At the same time, Leibniz reflects not only on the impossible but also on worlds (mundus). It is extremely curious that in the work On Simple Forms (April 1676; A75; Y14) he speaks about multiple worlds and not about possible worlds (cf. bellow; as well as in Kulstad 2002, 230-232). The difference is important - a multitude implies existence, presence of these worlds. During the same month (A71; Y10), he writes that there can be infinitely many other spaces (spatial) or words with different laws of motion (cf. the comment in Rescher 1996, 140). At times, Leibniz speaks explicitly about another rerum natura, another existing Universe, etc. ${ }^{12}$

All of this clearly shows the gradual, uncertain and slow shaping of the conceptual apparatus of the idea of possible worlds, but as the visit to the Hague approaches, the process intensifies and, more importantly, moves occasionally in the opposite direction to the multiplicity of existing worlds. But what is their connection to Spinoza?

\subsection{The Role of Tschirnhaus and the Multiple Worlds}

Tschirnhaus has known Spinoza since the early 1670s and is one of his closest friends, but also one of his critics; on the other hand, he also knows Leibniz, thanks to the recommendations for latter made on behalf of Henry Oldenburg from September 1675. Shortly thereafter, Tschirnhaus secretly introduces Leibniz into parts of Spinoza's Ethics. ${ }^{13}$ Tschirnhaus' role is extremely interesting $;{ }^{14}$ but here I will focus only on one aspect of his influence on Leibniz - the idea of the multiplicity of the worlds.

\footnotetext{
${ }^{10}$ Requisita: what, if not given, cannot exist.

${ }^{11}$ Immediately after the meeting with Spinoza the idea of the incompossibility entertains Leibniz again; not everything is compossible, as this would lead to absurdities, i.e. disharmony, not logical absurdity (Leibniz 1992, 105).

${ }^{12}$ Cf. the overview in Knuuttila 2013 about the strong influence of medieval authors on the unfolding of modalities and possible worlds.

13 "Mons. Tschimhaus m'a conte beaucoup de choses du livre Ms. De Spinosa" in "Über Spinozas Ethik" - AA VI, 3, 384 .

${ }^{14}$ For example, the text On the Origin of Things from Forms (Y13; Leibniz 1992, 74-83) clearly shows the influence of Tschirnhaus.
} 
In a letter from Schuller to Spinoza (No. 63, from 25. 07. 1675), in which he forwards questions to Tschirnhaus, we find an unexpected interpretation of the spinozist idea about the infinitely many attributes. Tschirnhaus (through Schuller) assumes there are as many different worlds, like the attributes God has. In each one of these other worlds the attribute of thinking is present (it is like a universal meta-attribute), but, instead of the extension, characteristic for our own world, there we have a different attribute, which is unknowable and incomprehensible to us. All creatures in these other worlds will reperceive only through two attributes - the thinking plus the attribute, which is specific for their own world. Spinoza does not, of course, agree with such a strange interpretation, and he points out the "Remark" to Theorem 7 (II part of Ethics; Spinoza 1981, 110-111). However, in this case we are interested in something else: the similarity between Tschirnhaus' interpretation of Spinoza and Leibniz's reflections from the period of his preparation for the meeting with Spinoza - both at the level of ideas, concepts, word order, and arguments (Kulstad 2002). However, this should not be surprising - Tschirnhaus and Leibniz discuss exactly Spinoza's texts.

Consequently, Leibniz will criticize the idea of multiple worlds, as well as the idea of the realization of all possibilities in our world. But in 1676 he seems to be at least inclined to reflect on the first option. But something happens before/during the meeting with Spinoza, and this will finally make him abandon the view about the multiplicity of the worlds. On December 12, 1676, shortly after his visit to Spinoza, Leibniz sums up: There is no need for the multitude of things to be increased by a plurality of worlds (Leibniz 1992, 102-103). The hesitations suddenly disappear.

\subsection{Manuscripts and Variants of the Text from the Meeting}

Almost none of the aforementioned problems, fluctuations, and excitements is explicitly present in the manuscript from the meeting. What Spinoza hears is just a methodological introduction of the possibility, which allows it to be thought through the idea of (in)compatibility and through the prism of the onto(theo)logic. Prior to the visit, Leibniz develops at least several variants of the proof, so that we have access to three different manuscripts, including A81: A79. Quod Ens Perfectissimum Sit Possible (AA VI:3, 572574; 1992: 90-95) from November 1676; A80. Ens Perfectissimum Existit (AA VI:3, 575577; 1992: 96-101) from November 1676; A81. Quod Ens Perfectissimum Existit (AA VI:3, 578-579; 1989: 167-168; 1992: 100-103) from 18-21 November 1676.

\subsection{A81: That a Most Perfect Being Exists}

As a starting point I will take the last manuscript (A81) - the text which was presented to Spinoza. ${ }^{15}$ I will not comment on the validity of the argumentation, the assuming of the opposite as a method or the procedure through definitions (more about the argumentation in Lomasky 1970; Blumenfeld 1972; Werther 1996; Nachtomy 2011, as well as in Blumenfeld 1995, 357-364); in this case, only the individual claims are important. To this end I provide a structured analysis, which follows the chronology of

\footnotetext{
${ }^{15}$ On the other side of the paper there are written with the handwriting of Leibniz references to the following theorems from the Ethics: 2, 5, 10, 22, 23, the Scholium to 31 - all from part I; and to the Theorems 19, 22, 26, 29, 49 from part II; cf. AA 11, 1, 427-428.
} 
the exposition and distinguishes the individual steps. The steps match the paragraphs except for $4-5$, where - as I have noted - the fourth paragraph of the manuscript covers steps 4 and $4 \mathrm{a}$, and the fifth paragraph covers the steps from $4 \mathrm{~b}$ to 5 inclusive.

1. Definition: "Perfection" is a simple quality, which is positive and absolute [§1];

2. Unfolding of the Definition: Every simple thing is unanalyzable (it is not an aggregate) and indefinite (cannot be understood through negation, through boundaries) [\$2];

3. Theses to be Proved: All perfections are compatible with each other (in one subject) [§3];

4. Proof by Assuming the Opposite: We take the proposition "A and $\mathrm{B}$ are incompatible", where A and B are perfections cf. (step 1) [\$4-5];

a. The proposition "A and B are incompatible" is unverifiable, because A and B are unanalyzables (steps 4, 1 and 2);

b. The proposition "A and B are incompatible" is not self-evident;

c. All necessity true propositions are either verifiable, or self-evident;

d. Hence, the proposition "A and B are incompatible" is not a necessarily true proposition;

e. Hence, A and B may be in the same subject.

5. Consequence: All perfections (A, B, C...) are compatible [§5];

6. Consequence: There is a present or intelligible subject of all perfections, or $a$ perfect being [§6];

7. Consequence: Existence is perfection and therefore a most perfect being exists [§7];

8. [Later added] Scholium: Here we have a brief reflection on Descartes, in which the unsubstantiated Cartesian premise (that a most perfect being is possible without any proof) is criticized. From the fact that it is possible, of course, directly follows the existence, but for Leibniz the possibility has to be proven (cf. steps 1-7).

\subsection{A79: That a Most Perfect Being is Possible}

From now on I will refer through the numbering in triangular brackets to the just exposed steps in A81. After the statements, which later do not appear in A81, I will simply put $\langle 0\rangle$.

It is the first half of November 1676, shortly before his meeting with Spinoza. Leibniz begins his exposition with a sense of discovery. He suspects that he has found proof that a most perfect being is possible (the latter does not involve a contradiction ${ }^{16}$ ). The text is visibly narrative and Leibniz explains that it will be sufficient to prove that all the positive attributes are compatible $\langle 3\rangle$. Even in the first sentence the following concepts are presented as synonyms: essences, qualities, positive attributes; for short, I will refer to this line of synonyms as EQA $\langle 0\rangle$. Leibniz distinguishes between two kinds of attributes: analyzable and unanalzable $\langle 0\rangle$ and from here it follows that it is sufficient to show the compatibility only of the basic, unanalyzable attributes, it is even sufficient only to point out any two unanalyzable attributes $\langle 1-2\rangle$. So there is analyzability (aggregates; composites) and non-analyzability (primitiveness) of EQA. The primitive EQA are

\footnotetext{
${ }^{16}$ The possible is logically defined as what does not consist in itself contradiction: “...sit possibile, seu non implicet contradictionem" (Leibniz 1992, 90).
} 
perceived through themselves <0>: sive quae per se concipiuntur (Leibniz 1992, 90). Leibniz continues with the assumption of the opposite: "[EQA] A and B cannot be in the same subject" $<\approx 4>$. In order to be necessarily true, it has to be either proven, or to be an identical proposition $<\approx 4 \mathrm{c}>$. Leibniz now considers "Where A is, B cannot be" and claims two things about it:

1. It is not an identical proposition, because these must be positive EQA, and in the case A would be a negation of B.

2. It cannot be said, since the proof requires analysis of at least one of the two attributes, or of both simultaneously, and EQA are unanalyzable <4a-b>.

Therefore, the incompatibility cannot be demonstrated or proved (Leibniz 1992, 93) $\langle 4 \mathrm{~d}\rangle$, i.e. all EQA are compatible $<5>$. There may be a creature with all simple EQA $<\approx 6 ; 4 \mathrm{e}>$.

At least at first glance, the deviations from A81 are not that great. However, the manuscript continues and strengthens the differences (hereafter everything is marked $<0>$ ). In the following paragraph, Leibniz attempts to show that this most perfect being is necessary, but the argument is different from $\langle 7\rangle$ : God's existence in this case is not the main goal; this is evident from the title of the manuscript. According to Leibniz, the impossible is that which has no (external or internal) reason for its existence. ${ }^{17} \mathrm{~A}$ most perfect being does not have an external reason, therefore, it is either impossible (which contradicts to $\langle 6\rangle$ ), or has an immanent reason in itself, that is, it is necessary. This is a very curious argument in the style of "Spinoza"; however, the analogy does not stop here. Right after that Leibniz points out two important things - every positive attribute is infinite, and the negative affections (that is, the modes) result from the multiplicity of positives attributes. Here, the closeness to Spinoza's structure, topics and terminology is intrusive; Leibniz is obviously preparing for the meeting. The next paragraph is even more impressive: all things differ not substantially (radically), but only modally; if we are leibnizians, we should have put an exclamation mark here. The radical (substantial) difference means that the thing is understood per se - without any other - through all its own characteristics (omnia requisita) and without any relation to some foreign characteristics (cf. Ethics, part 1, Def. 3). But, in terms of things, for Leibniz it is obvious that they have common reason and common characteristics, and hence - common essence. Therefore, things differ only modally, ${ }^{18}$ i.e. they do not differ from each other, and everything is one, as Plato had said in Parmenides (Leibniz 1992, 95).

The manuscript also ends in an unexpected way. First, with a description of how the metaphysical text is to be composed - necessary are only proofs about things that contradict common belies, and this is in direct connection with Leibniz's repeated criticism to Spinoza about the alloglossia and logomachia in his texts (Lærke 2009). Second, it ends with definitions of the main concepts in the exposition - attribute, affection, essence, - and these definitions partially imitate the concepts and the approach of the Ethics.

\footnotetext{
17 "Ergo vel nullam habere potest existendi rationem, adeoque impossibile est" - AA V1, 3, 572; $1992,92$.

${ }^{18}$ Leibniz gives as an example a town and the various perspectives to it - seen from above or from a plain.
} 


\subsection{A80: A Most Perfect Being Exists}

The chronologically next manuscript is different from a stylistic point of view instead of being narrative and descriptive, the exposition is rather argumentative (with many additions or clarifications). It begins with the following statement: "The perfections, or the simple forms, are either absolutely positive qualities, or indefinable and unanalyzable" $\langle 1-2\rangle$. Here we find again a synonymous order, similar to EQA, but the absences of the spinozists concepts "attribute" and "essence" (replaced by "simple forms" and "perfections") are intrusive. What is preserved are the qualities $\langle 1\rangle$. The interesting part is that Leibniz adds that indefinable and unanalyzable are also our thoughts about these qualities (compare with the views from autumn of 1675).

Leibniz then explicitly states (following Plato's Theaetetus) that a proposition with an unanalyzable subject cannot be proved (all general propositions are proved by analysis of the subject, Leibniz 1992, 97, 99); this claim cannot be found explicitly in A81, but is hidden in $\langle 4 a\rangle$. On the other hand, the necessary and unprovable propositions are identical or they are variations on coincidence $\langle 0\rangle$. Any true, universal and necessary proposition is either unprovable (identity), or provable $<\approx 4 c>$. From here on Leibniz proceeds to the consideration of the impossibility of the existence of $\mathrm{A}$ and $\mathrm{B}$ in the same subject and demonstrates that this is not identity, and it cannot be proved $\langle 4 \mathrm{a}-\mathrm{e}\rangle$. After that in quick succession $\langle 5,6,7\rangle$ follow. Leibniz adds: existence is a perfect, simple form, an absolutely positive quality (Leibniz 1992, 97).

The following two paragraphs explain: first, that for the proof of the necessary existence it is sufficient to be shown that it is possible $<\approx 8>$; and, secondly, (in a long note), the relationship between analysis and proof in themselves is explained $\langle 0\rangle-$ extremely interesting reflections, for which we do not have time and place here. However, the most curious thing is that the manuscript ends with an annex, which is almost identical to manuscript A81, written in front of Spinoza. This means that Leibniz has refined the argumentation even before the meeting, as the differences are almost able to be fully neglected. Everything needless is removed and he arrives at the Hague with his arithmetic machine and thoughts about the possibility.

\section{ANSWERS AND ADDITIONAL COMMENTS}

The comparison of the three manuscripts reveals several important points:

Possibility. The consistent clarification of the argumentation and, more importantly, the gradual disappearance of the terms and topics, introduced by Spinoza, are evident (half of the $\langle 0\rangle$ claims). On the other hand, the comparison allows us to see that the argument is directed precisely against the philosophical grounds of Spinoza and this is done through "Spinoza" himself.

Compossibility. Secondly, according to Leibniz the incompatibility cannot be proved with respect to any simple, positive qualities, i.e. they are all compossible. This has a direct relation to the intuition (from the autumn of 1675) that we cannot speak about the possibility of a thing just from the fact that its characteristics are thought separately. Moreover, the qualities are connected in a single subject and thus the topic about the multiplicity is partly overshadowed by that of compossibility. Yes, all perfect qualities are compatible, but this immediately opens the way also to the incompossibility of other qualities (or possible worlds). Let us recall that in February he claims: together, all 
possibilities (and not only the simple qualities) cannot be understood by anyone, as they suggest contradiction.

Analysis. Thirdly, Leibniz attempts to create a different method, but parallel to the mathematics analyticalone, the objects of which are basic, indivisible and indefinable qualities (this has some well-known and long-term consequences: the monads). However, as it is evident in A81 part from the key moments are premised: the connection between analysis and proof, as well as $\langle 4 \mathrm{c}\rangle$.

Let us now go back to the main issues. The answers down below are incomplete but they outline some framework and in this sense they resemble an initial sketch:

Why did Leibniz visit Spinoza? Apart from everything else, this is a desire to test Spinoza's thesis (as Leibniz understands it) that everything happens by an absolutely necessity. The direct meeting ensures this verification. As a result Leibniz will be terrified that he has come so close to the "precipice" of necessity (Leibniz 1989, 263266). So the introduction of contingency and possibility is the only way by which the philosophy can continue.

Why did his preparation for the meeting (and the visit itself) include this modification of the ontological proof of God? Leibniz's argumentative move is extremely interesting: according to him, in the case of Descartes and in that of Spinoza there is a serious oversight, because before the proof of the necessity of something, first its possibility has to be proven (why God has infinitely many attributes in Spinoza, is this possible, can it be proved?). The most elegant way to introduce this inclusion of the problem of possibility, without causing a direct conflict, is through the triviality of the ontological proof (something, which was accepted and exposed by both Descartes and Spinoza). On the other hand, this is the most fundamental introduction of possibility at all, and from now on it is going to be a main concept in ontology.

What is the philosophical result of the meeting and what do possible worlds have to do with it? The result is that Leibniz abandons the idea about the multiple existing worlds - in the interpretation of Tschirnhaus this idea is associated precisely with Spinoza and the infinitely many existing attributes of God. Instead, Leibniz offers an analysis of the qualities and finally accepts the idea of possible worlds; and so the problem about the necessity is "resolved" through free will and the principle of sufficient reason. From now on, Leibniz's philosophy unfolds in a single direction/system; the reconceptualizations of his ideas become stable; even his objections to his contemporaries often repeat the objections to Spinoza. The meeting also has some extremely important implications in the history of philosophy:

- in terms of rationalization of the possibility as a whole;

- in terms of the role of the transcendental philosophy a hundred years later, and

- even in terms of the reduction of the modalities in the contemporary analytic tradition.

But those three are other and different stories. However, since the purpose of this historical review is to move gradually to the contemporary problematic, this inquiry is just a prelude. 


\section{REFERENCES}

Blumenfeld, David. "Leibniz's Modal Proof of the Possibility of God". Studia Leibnitiana 4, 2 (1972): 132-40.

. "Leibniz's Ontological and Cosmological Arguments". In The Cambridge Companion to Leibniz, edited by Nicholas Jolley, 353-81. Cambridge: Cambridge University Press, 1995.

Knuuttila, Simo. "Medieval Theories of Modality", 2003. http://plato.stanford.edu/archives/fall2013/entries/ modality-medieval.

Kulstad, Mark A. "Leibniz, Spinoza, and Tschirnhaus. Metaphysics À Trois, 1675-1676". In Spinoza: Metaphysical Themes, edited by Olli I. Koistinen and John I. Biro, 221-40. Oxford: Oxford University Press, 2002.

Lærke, Mogens. "The Problem of Alloglossia. Leibniz on Spinoza's Innovative Use of Philosophical Language". British Journal for the History of Philosophy 17, 5 (2009): 939-53.

Leibniz, Gottfried. Confessio Philosophi. Papers Concerning the Problem of Evil, 1671-1678. Translated by Robert C. Sleigh. The Yale Leibniz, edited by Daniel Garber and Robert C. Sleigh New Haven: Yale University Press, 2005.

. De Summa Rerum. Metaphysical Papers, 1675-1676. Translated by G. H. R. Parkinson. The Yale Leibniz, edited by Daniel Garber and Robert C. Sleigh. New Haven: Yale University Press, 1992.

. "Gottfried Wilhelm Leibniz: Sämtliche Schriften Und Briefe". Darmstadt/Leipzig: Otto Reichl Verlag, $1923-\ldots$

Philosophical Papers and Letters. Translated by Leroy E. Loemker. The New Synthese Historical Library: Texts and Studies in the History of Philosophy, edited by Simo Knuuttila, II ed. Dordrecht: Kluwer Academic Publishers, 1989.

- Theodicy: Essays on the Goodness of God, the Freedom of Man and the Origin of Evil. Translated by E.M. Huggard. Charleston: BiblioBazaar, 2007.

Lomasky, Loren E. "Leibniz and the Modal Argument for God's Existence". The Monist 54, 2 (April 1970): 250-69.

Malcolm, Noel. "Leibniz, Oldenburg, and Spinoza, in the Light of Leibniz's Letter to Oldenburg of 18/28 November 1676". Studia Leibnitiana 35, 2 (2003): 225-43.

Nachtomy, Ohad. "A Tale of Two Thinkers, One Meeting, and Three Degrees of Infinity: Leibniz and Spinoza (1675-8) ". British Journal for the History of Philosophy 19, 5 (2011): 935-61.

Rescher, Nicholas. "Leibniz on Possible Worlds". Studia Leibnitiana 28, 2 (1996): 129-62.

Spinoza, Baruch. Complete Works. Translated by Samuel Shirley. Indianapolis: Hackett Publishing, 2002.

Stewart, Matthew. The Courtier and the Heretic: Leibniz, Spinoza, and the Fate of God in the Modern World. New York: W.W. Norton \& Company, 2006.

Vidinsky, Vassil. "Dynamical Interpretation of Leibniz’s Continuum". Kaygl 10 (Spring 2008): 51-70.

Werther, David. "Leibniz and the Possibility of God's Existence". Religious Studies 32, 1 (March 1996): 37-48

\section{MOGUĆI SVETOVI U BEZDANU: ZAŠTO JE LAJBNIC SREO SPINOZU?}

Osnovni cilj ovog rada je pružanje odgovora na tri važna pitanja. Zašto je Lajbnic posetio Spinozu? Zašto je njegova priprema za ovaj susret uključivala modifikaciju ontološkog dokaza o postojanju boga? Śta je filozofski rezultat ovog susreta i šta sa tim ima ideja mogućih svetovi? Da bismo dali odgovore na ova pitanja, upoređivaćemo paralelno tri Lajbicova rukopisa iz novembra 1676.godine, međusobno vrlo povezana. Uz to, analiziraćemo tri konceptualne promene u njegovoj filozofskoj aparaturi. Poslednji od ova tri rukopisa, Lajbnic je predočio Spinozi. Negde u to vreme Lajbnic je odustao od ideje o mnoštvu svetova (vidi: Tschirnhaus), i umesto toga predložio je ideju mogućih svetova, uvodeći time ovu u samu (onto/teo)logičku strukturu kako bi izbegao „bezdan“ Spinozine nužnosti. Ono što je zanimljivo, međutim, je zapravo kako se tačno ova konceptualna promena desila krajem 1676. godine $i$ šta su njene filozofske i metodološke implikacije.

Ključne reči: Lajbnic, Spinoza, mogući svetovi, mnoštvo svetova, ontološki dokaz za postojanje boga, kvaliteti. 